\title{
The Training Impact OF EXPERIENCE IN JANE AUSTEN's EMMa
}

\begin{abstract}
Jane Austen's Emma foregrounds the impact of experience on the central character's cognitive and emotional development. Experience also plays a key role in how the narrative is constructed. Having presented the impact of Emma's miscalculations about the other characters' intentions, the narrative shows how she grows mentally through her experiences and how they mould her character along time. As a result of her experiences, Emma's character gradually evolves into a more sympathetic one. Such a transformation brings about some meaningful re-evaluations in Emma's thoughts, judgments and behaviour. Likewise, in narrative studies, experience is taken as an inherent quality of narrative and is evoked in its reader. In this essay I argue that the representation of the impact Emma's personal experiences have on her should be taken as the most important aspect of Austen's narrative plot and as the basic condition for its understanding.
\end{abstract}

\section{Keywords}

Narrative and experience; human (or anthropomorphic) experience; postclassical narratology; Emma; Jane Austen

\section{Introduction}

F. R. Leavis includes Jane Austen in his list of the "great English novelists" (1950: 1). Leavis ascribes Austen's greatness to her "formal perfection" which "can be appreciated only in terms of the moral preoccupations that characterize the novelist's peculiar interest in life" (1950: 8). Leavis also considers Austen's "moral preoccupations", or what Wayne Booth terms as Austen's "broad range of moral judgment" (1961: 158), as the primary factor in the greatness of her novel Emma, 
'Those who suppose it to be an 'aesthetic matter', a beauty of 'composition' that is combined, miraculously, with 'truth to life', can give no adequate reason for the view that Emma is a great novel, and no intelligent account of its perfection of form" (Leavis 1950: 8). Likewise, according to Booth, more than anything else, Emma presents humane virtues since "when we read this novel [Emma] we accept her as representing everything we admire most" (1961: 265). This narrative quality leads to our "sympathy for Emma" (Booth 1961: 249). With the help of some modern narrative techniques, such as narrative situation (focalization) and mode (free indirect thought), Austen enables her readers to share Emma's feelings and experiences and thus evaluate the gradual process of her change. Through decreasing the distance between the reader and the characters, Austen deliberately manipulates the reader's experiencing process. In other words, by the end of the narrative, the reader has learned from Emma's experiences. As noted by Elaine Showalter, the presented lifelike issues in Austen's novels are, however, mostly female related. Austen wrote "in the direction of an all-inclusive female realism, a broad, socially informed exploration of the daily lives and values of women within the family and the community" (1977: 29).

Emma can be read as an experiential narrative. According to Gregg A. Hecimovich (2008), in Emma "Austen represents the way people actually experienced living, not only what their lives looked like [...] but also the process by which they understand, or fail to understand their lives" (14). Nearly all the narrative events and situations, particularly in the first and second volumes, are expressed in the tenor of Emma's thoughts and actions or, as John Wiltshire (1997) observes, "in the vicinity of Emma, the narrative picks up her tone, her expressions, her phrasing, even when it is not formally committed to rendering her speech or thought-patterns" (66). Emma's remarkable change, however, does not take place rapidly. In her relationships with the other characters, she goes through some serious miscalculations and misjudgements which are constructive for her character to develop. David Lodge (2002) considers this characteristic a general feature of the genre novel, writing that "the heroes and heroines of most novels are involved in a social world where the achievement of their goals requires constant adjustment of their own beliefs, and the correct understanding of other people" (42-43). From this viewpoint, Emma is a true Austenian character since, as Janet Todd (2006) highlights, "in Austen's novels moments of self-recognition come rather from the heroines' own experience" (21). Austen's realism is, however, different from the more common concept of the term which refers to the novels portraying "ordinary events and people in commonly identifiable situations" (Townsend 2010: 263). Revising Walter Scott's theory of didactic realism in Emma, Heather M. Klemann argues that "Emma's didacticism extends beyond the purview of realism and its controls" (2012: 504). Therefore, he suggest that "the parody of literary form, in addition to a fealty to 'real life,' constitutes the didactic in Emma. Austen is not just a precision copier of lived context, but also, and as importantly, a deft manipulator of genre" (2012: 504). Klemann borrows from Susan Stewart to clarify what he means, "Austen, like all novelists, does not 
describe 'lived experience ... but the conventions for organizing and interpreting that experience"' (2012: 504). In this essay, I mainly argue that Emma's cognitive and emotional transformation towards the end of narrative is due to her ability to organize and interpret her lived experience throughout the narrative. Such an anthropomorphic narrative quality facilitates our enactment of the narrative meaning because, as Yanna B. Popova states, "narrative is based on a similar perceptually based mechanism that we rely on to automatically organize experience when perceptually given" (2015: 7).

Experience, therefore, can be taken as the central aspect of narrative in Austen's works. Austen's characters share many traits of actual people. As G. H. Lewes emphasised, "to read one of her books is like an actual experience of life: you know the people as if you had lived with them, and you feel something of personal affection towards them" (Southam 2005: 155). What makes her characters more lifelike, according to Lewes, is the fact that in her narratives Austen never "transcend[s] her own actual experience, never does her pen trace a line that does not touch the experience of others. Herein we recognize the first quality of literature" (Southam 2005: 156). As a result, we tend to get involved in the experiences of her characters, or, as Lewes holds, her characters "become equal to actual experiences" (Southam 2005: 167). In this sense, Emma's life and experiences reveal common points with our own. Her mistakes and their constructive impact on her character are the main concerns of Austen's narrative.

\section{Narrative research and the representation of experience}

Experience plays a significant role in narrative research. Influenced by readerresponse criticism, cognitive narratology pays close attention to both the function of experience in narrative and the reader's constructive role in experiencing and understanding a text. The first narratologist who drew attention to the significance of experience in narrative, Monica Fludernik (2005), named this function experientiality, or "the quasi-mimetic evocation of real-life experience" (9). Fludernik considers the representation of experience to be the defining feature of any narrative. Narrativity, according to her, "centres on experientiality of an anthropomorphic nature" (emphasis original, 19). As Fludernik understands it, the embedded cognitive parameters in narrative, which have the potential to evoke real-life experiences, activate the reader's natural cognitive responses. Despite her belief in the representability of experience in narrative, Fludernik does not define this representability in terms of narrative producers and recipients. This aspect of her theory has been seriously questioned by many narrative scholars. Marco Caracciolo (2012), for example, agrees with David Herman's redefinition of the term, arguing that experientiality "depends on the strength of the 'impact' a story has on its producers and recipients. In making a case for this, I will follow David Herman's suggestion that experientiality can be thought of as 'the impact 
of narrated situations and events on an experiencing consciousness"' (181-182). Following Herman, Caracciolo questions the embedded nature of experience in Fludernik's theory. As he argues, more than being "semiotically represented in narrative," experientaility "depends on the involvement of stories" in the reader's life experiences (2012: 181). In other words, Caracciolo thinks that a reader's understanding of narrative meaning depends on "enacting a particular character's consciousness" (Popova 2015: 6). Popova, however, argues that besides depending on a particular character's experience, reader's sense-making processes rely on "the always present interplay between perspectives [...] This, in turn, does not exclude the possibility of enacting a particular character's consciousness, although contexts in which internal focalization dominates the narrative are the most likely candidates for this to happen" (2015: 7). This is quite relevant to Emma in which narrative process is controlled not by one particular character's consciousness but by the perspective of the other characters and the narrator.

Unlike Fludernik, Herman (2009) does not think that experientiality should be taken as the only defining feature of narrativity. As he argues, "capturing what it's like to experience storyworld events constitutes a critical property of but not a sufficient condition for narrative" (141). Still, Herman considers (re)presentation of experience a "critical" part of any narrative. Furthermore, he believes that there are only degrees of narrativity. In other words, narratives are different from each other in terms of their narrativity levels, which depend not solely on the semiotic features of the text, but on the textual potential to evoke real-life experiences as well. Referring to it as qualia, or the what-it's-like dimension of narrative, Herman argues, "narrative roots itself in the lived, felt experience of human or human-like agents interacting in an ongoing way with their cohorts and surrounding environment" (2009: 21). In this way, he binds narrativity to the issues of qualia and consciousness, saying "the research at issue suggests not only that narrative is centrally concerned with qualia, a term used by philosophers of mind to refer to the sense of what it's like for someone or something to have a particular experience, but also that narrative bears importantly on debates concerning the nature of consciousness itself" (2009: 144). As a result, narratives, in Herman's understanding, generally provide the conditions for the reader to understand "what it is like for human or human-like agents to undergo experiences in storyworlds" (2009: 142). Therefore, both Fludernik and Herman, although from different perspectives, agree on the constructive role of experience in narrative. Narrative meaning, according to them, is an effect of this basic narrative quality since, as Popova holds, "characters' experiences and the reader's experiential enactment of them provide a valuable [...] access to the meaning of a story" (2015: 6).

This essay, likewise, argues that experience acts as a basis for the gradual change of Emma's thoughts and evaluations, and, at the same time, it has the potential to enhance the reader's involvement in narrative understanding. The present essay analyses the way Emma's life experiences bring about her behavioural and cognitive changes. Her anthropomorphic experiences engage readers 
cognitively, and the represented situations and events encourage reader participation both mentally and emotionally. Emma's experiences throughout the novel construct the overall structure of the narrative plot such that the entire narrative can be seen as a representation of Emma's experiences in relation with that of the other characters. What makes Emma's change possible is her realisation, mostly with the help of Mr. Knightley, that her evaluations, thoughts, values and interests can only exist alongside those of the other characters.

\section{Emma Woodhouse and her experiences}

Emma's experiences throughout the narrative gradually affect her thoughts about herself and her evaluations of the other characters. The narrative structure demonstrates this change as well. Emma's late recognition of her self-deception about Mr. Elton's interest in Harriet is presented in the first volume. The second volume shows how she finally is able to recognise that Frank Churchill and Jane Fairfax are in a romantic relationship. The last volume illustrates her inability to resist expressing her love for Mr. Knightley. Her belated acknowledgement of her feelings and mistakes to herself and to Mr. Knightley is a confession of her mistakes that have been highlighted and constructively criticised by Mr. Knightley from the beginning of the novel. Such self-recognition is caused by the consequences of some serious miscalculations Emma makes about the other characters. The narrative recounts how she is finally able to control her imagination, or at least attenuate it. Although she comes to this realisation later than Mr. Knightley and the reader, Emma finally understands that her unrealistic imagination is the real source of her problems. This process, however, does not happen easily.

Emma's primary character trait at the beginning of the novel is her apparently unrealised egocentricism. She is obsessed with imagining the pros and cons of other characters' thoughts and intentions; as the narrator describes her, she is continuously "on fire with speculation" (Austen 1998: 309) This side of her character is mainly shown through her incessant pursuit of an unavoidable desire - matching people up, which she finds the "greatest amusement in the world!" (Austen 1998: 13) The omniscient narrator's comments and interpretations, however, reveal the paradox between Emma's thoughts about the other characters and their reality. This contradiction, highlighted by "the corrective function of the narrator" (Ermarth 1998: 146), enables the reader to closely observe the process through which Emma's perspective towards some central events, situations, characters and their actions finally changes. Before these changes, Emma resembles a writer whose mind uncontrollably operates based on what she imagines about the other characters' intentions. Not recognising the border between these imagined thoughts and reality, she (un)consciously mixes the real realm with the fictional one. She considers her own imaginary evaluation of all the significant narrative situations to be the only real one in the same way that she considers her first matchmaking experience a "success" (Austen 1998: 14). However, the 
novel reveals that she only imagines the other characters' mental states and intentions, as she is limited to her own perspective. Mr. Knightley constantly warns her about this problem, reminding her that what she calls her "success" is only her imaginary "planning" without any practical "endeavour" (Austen 1998: 14).

Emma's vanity is presented from the beginning of the novel. She has a strong tendency to believe that she and her father are superior to any other person in Highbury, and therefore thinks she knows what is good or bad for everyone else in Highbury and wants to be the author of any change in the neighbourhood. Emma's resistance to any kind of change, either in her environment or her thoughts, that she does not control is portrayed at the beginning of the novel:

The real evils, indeed, of Emma's situation were the power of having rather too much her own way, and a disposition to think a little too well of herself; these were the disadvantages which threatened alloy to her many enjoyments. The danger, however, was at present so unperceived, that they did not by any means rank as misfortunes with her. (Austen 1998: 7)

The "evil" nature of her "situation" and her high (and mostly misplaced) confidence in her own character primarily comes from those around her. Along with her father's gross exaggeration of her abilities, it is because her tutor, Miss Taylor, fails to enforce any educational policy for her first sixteen years that Emma thinks so highly of her own judgements. After her mother's death, Emma replaced her in the household, and her tutor-student relationship with Miss Taylor changed into a friendly one. As a result, an unrealistic perception of both her own potential and that of others has overcome Emma's thoughts. Miss Taylor's marriage gives Emma pain, as she knows she no longer has anybody like Miss Taylor to praise her, listen to her and obey her unquestioningly. She is confused by not knowing how to deal with the new situation ("How was she to bear the change?" (Austen 1998: 8)) and has mixed feelings about Miss Taylor's marriage. While she feels pleased by the thought that she caused Miss Taylor's marriage with Mr. Weston, she is disappointed that the marriage has now left her alone. It is implied that Emma has inherited her anxiety about change from her father, who is represented as "hating change of every kind. Matrimony, as the origin of change, was always disagreeable" (Austen 1998: 9). Change for Mr. Woodhouse is associated with melancholy and sadness. Towards the end of the novel, Emma admits to Mr. Knightley, that "while her dear father lived, any change of condition must be impossible for her. She could never quit him" (Austen 1998: 414). Likewise, Emma's abhorrence of change is revealed at every turn. She does not accept any changes in her attitude towards marriage. When Harriet says to her, "I do so wonder, Miss Woodhouse, that you should not be married, or going to be married! so charming as you are!'” Emma's response reveals her inflexible attitude:

'I have none of the usual inducements of women to marry. Were I to fall in love, indeed, it would be a different thing! but I never have been in love; it 
is not my way, or my nature; and I do not think I ever shall. And, without love, I am sure I should be a fool to change such a situation as mine. Fortune I do not want; employment I do not want; consequence I do not want: I believe few married women are half as much mistress of their husband's house as I am of Hartfield; and never, never could I expect to be so truly beloved and important; so always first and always right in any man's eyes as I am in my father's.' (Austen 1998: 81)

Through her experiences, Emma breaks with some of these initial convictions. Her experiences spur her cognitive growth around which the narrative is structured. She initially thinks that she cannot fall in love, let alone marry, but her experiences help her develop social maturity and prepare her to understand the social codes of adult life. This knowledge, together with her sensibility, brings a balance to her character. Furthermore, it provides the reader with the chance to re-evaluate her own perceptions of Emma's character. Before representing the moment when Emma and Mr. Knightley mutually agree to marry, the novel recounts some dramatic events and situations which are fundamental to Emma's development.

\subsection{Emma and Harriet Smith}

Harriet Smith is an integral part of Emma's life and experiences. Because of her need for praise, Emma immediately tries to substitute Harriet for her former companion, Miss Taylor. Harriet is the only available person in the neighbourhood who Emma finds appropriate to be made her new "project." She thinks she can "improve" Harriet and then introduce her "into good society" (Austen 1998: 24). Harriet's readiness to "worship her friend" (Austen 1998: 380) at every chance adds negatively to Emma's own irrational sense of self-importance and her conviction that Harriet can move in high society. Harriet's lack of self-confidence allows Emma to persuade her to reject Mr. Martin, her social and romantic equal, in favour of Mr. Elton and Frank Churchill. Both attempted matches prove to be the wrong choice. Such experiences of failure have a profound impact on Emma's character. She ultimately admits that all her matchmaking attempts have resulted in failure due to her own mistakes, and privately acknowledges that she has helped Harriet change from humble to vain. For example, she blames herself for what she did to Harriet in encouraging her to pursue Frank Churchill: "Poor Harriet! to be a second time the dupe of her misconceptions and flattery" (Austen 1998: 372). Despite such mistakes, when she finds out that Harriet is developing romantic feelings for Mr. Knightley, she is deeply affected: "She touched — she admitted — she acknowledged the whole truth. [...] It darted through her, with the speed of an arrow, that Mr. Knightley must marry no one but herself!" (Austen 1998: 377). Here, Emma finally begins to re-evaluate what she has done to Harriet:

Mr. Knightley and Harriet Smith!- - It was a union to distance every wonder of the kind. - [ . . . Such an elevation on her side! Such a debasement on 
his! [...] - Could it be? —No; it was impossible. And yet it was far, very far, from impossible.-Was it a new circumstance for a man of first-rate abilities to be captivated by very inferior powers? Was it new for one, perhaps too busy to seek, to be the prize of a girl who would seek him?-Was it new for anything in this world to be unequal, inconsistent, incongruous - or for chance and circumstance (as second causes) to direct the human fate? (Austen 1998: 382)

The possibility of a serious relationship between Harriet and Mr. Knightley evokes Emma's heightened emotions and contributes to her self-development. According to Ermarth (1998), "when Harriet discloses her interest in Mr. Knightley, Emma experiences the perturbing 'development of self' (III, xi, 321) that reminds her of her place" (161). Emma's envious evaluation of Harriet's interest in Mr. Knightley allows her to profoundly analyse the new situation. Unlike her previous evaluations of similar situations, Emma gets to the root of the problem this time. She also finds that she herself is the main cause of Harriet's belief that Mr. Knightley has feelings for her:

She had brought evil on Harriet, on herself, and she too much degree she herself feared, on Mr. Knightley.-Were this most unequal of all connexions to take place, on her must rest all the reproach of having given it a beginning; for his attachment, she must believe to be produced only by a consciousness of Harriet's; - and even were this not the case, he would never have known Harriet at all but for her folly. (Austen 1998: 382)

Through such critical reflections, Emma gradually learns to apply logic to her own imagination. In looking at her past actions, she identifies her own mistakes and belatedly agrees with Mr. Knightley that she has had a negative influence on Harriet. Having realised her mistake once her self-interest is at stake, Emma is now able to evaluate the new situation critically:

How Harriet could ever have had the presumption to raise her thoughts to Mr. Knightley!- How she could dare to fancy herself the chosen of such a man till actually assured of it! - But Harriet was less humble, had fewer scruples than formerly.-Her inferiority, whether of mind or situation, seemed little felt. - She had seemed more sensible of Mr. Elton's being to stoop in marrying her, than she now seemed of Mr. Knightley's.-Alas! was not that her own doing too? Who had been at pains to give Harriet notions of self-consequence but herself?-Who but herself had taught her, that she was to elevate herself if possible, and that her claims were great to a high worldly establishment?-If Harriet, from being humble, were grown vain, it was her doing too. (Austen 1998: 383) 
This scene is the real moment of Emma's awakening. She rearranges her thoughts not only about her influence on Harriet, but also about her own character. When she looks deep into her heart and mind, she also discovers Mr. Knightley's love for her and blames herself for denying it for a long time. The qualia or the felt quality of her experience here deeply affects her manner of thinking:

The rest of the day, the following night, were hardly enough for her thoughts. [...] Every moment had brought a fresh surprize; and every surprize must be matter of humiliation to her-- How to understand it all! How to understand the deceptions she had been thus practising on herself, and living under!The blunders, the blindness of her own head and heart! [...] in every place, every posture, she perceived that she had acted most weakly; that she had been imposed on by others in a most mortifying degree; that she had been imposing on herself in a degree yet more mortifying; that she was wretched, and should probably find this day but the beginning of wretchedness. (Austen 1998: 381)

Emma learns from her own experiences through this self-reflective inner discourse. Similarly, Harriet also grows through her own experiences. Towards the end, she learns how to proclaim and defend her own thoughts, which are more realistic than the earlier fancies that Emma encouraged. When she reveals to Emma that she will "never marry," not because of Mr. Elton, but because of a person who is "so superior to Mr. Elton," she shows more self-esteem and determination. Although Emma misinterprets Harriet's words at the beginning of this speech, thinking that she is referring to Mr. Knightley, she evaluates the consequences of her words to Harriet by taking "a longer time for consideration" before she speaks to her. Instead of any attempt to impose her own thoughts on her, she encourages Harriet to be prudent:

'Consider what you are about. Perhaps it will be wisest in you to check your feelings while you can: at any rate do not let them carry you far, unless you are persuaded of his liking you. Be observant of him. Let his behaviour be the guide of your sensations. I give you this caution now, because I shall never speak to you again on the subject. I am determined against all interference. Henceforward I know nothing of the matter.' (Austen 1998: 316)

Emma's acquaintance with Harriet and her subsequent active involvement in the relationships between Mr. Martin and Harriet, Mr. Elton and Harriet and Frank Churchill and Harriet all help her to mature. Although she rarely admits her mistakes publicly, we can observe how she privately acknowledges some of her misconceptions about other people's intentions. The behavioural lessons she gains from such experiences help her to grow both emotionally and cognitively. 


\subsection{Emma and Mr. Elton}

Emma's failure to match Harriet with Mr. Elton is the first narrative situation wherein her unquestioned reliance on her own inferences is shaken. Having dissuaded Harriet from accepting Mr. Martin's proposal at the beginning, Emma tries to match her with Mr. Elton, who is described by Mr. Knightley as "a very good sort of man, and a very respectable vicar of Highbury" (Austen 1998: 63). This leads to Emma's first serious disagreement with Mr. Knightley, who thinks that Robert Martin is a better match for Harriet than Mr. Elton. The narrative unfolds as Mr. Knightley predicts. Even before she meets Harriet, Emma is already concerned with Mr. Elton's situation. She misreads his reaction to the Westons' marriage ceremony, "II thought when he [Mr. Elton] was joining their hands today, he looked so very much as if he would like to have the same kind office done for him!'" Here she colours facts with her own fancies, which is her usual way of evaluating such situations. Encouraged by Miss Taylor's marriage and the role she believes she played in making that happen, Emma feels obliged to do something for Mr. Elton and tries to channel all of Harriet's attention towards him. Emma encourages Harriet to reject Mr. Martin's proposal so that she can match her with a person of higher social status. Through the implications of the narrator and Mr. Knightley's open warning, however, the reader already knows that Emma is wrong in her evaluation of this situation, as Mr. Elton is not in love with Harriet but with Emma herself. Furthermore, the reader is able to identify that Emma's mistake mainly derives from her natural tendency to fictionalise factual issues. As we are told:

She was quite convinced of Mr. Elton's being in the fairest way of falling in love, if not in love already. She had no scruple with regard to him. He talked of Harriet, and praised her so warmly, that she could not suppose anything wanting which a little time would not add. His perception of the striking improvement of Harriet's manner, since her introduction at Hartfield, was not one of the least agreeable proofs of his growing attachment. (Austen 1998: 40-41)

Emma's imagination affects her behaviour; the more she observes Mr. Elton's (re) actions in different situations, the more she believes he is in love with Harriet. She also believes that Harriet's feelings for Mr. Elton are developing under her own "direction." Through her long moments of reflection rendered to us through free indirect thought mode, we can see how Emma plans the match for both characters:

Emma could not feel a doubt of having given Harriet's fancy a proper direction and raised the gratitude of her young vanity to a very good purpose, for she found her decidedly more sensible than before of Mr. Elton's being a remarkably handsome man, with most agreeable manners; and as she had 
no hesitation in following up the assurance of his admiration by agreeable hints, she was soon pretty confident of creating as much liking on Harriet's side, as there could be any occasion for. (Austen 1998: 40)

Following these counterfactual fancies, Emma wrongly interprets a charade given to her by Mr. Elton, making an incorrect inference about the last two lines of the charade, “"Thy ready wit the word will soon supply, / May its approval beam, in that soft eye!"' She involuntarily assigns (irrelevant) references to the main words in these lines based on her own fancies:

She cast her eye over it, pondered, caught the meaning, read it through again to be quite certain, and quite mistress of the lines, and then passing it to Harriet, sat happily smiling, and saying to herself, [. . . "Very well, Mr. Elton, very well, indeed. I have read worse charades. [. . . This is saying very plainly'Pray, Miss Smith, give me leave to pay my addresses to you. Approve my charade and my intentions in the same glance."' (Austen 1998: 69)

Emma uses this interpretation to further reject what Mr. Knightley once said about Mr. Elton: “"Ah! Mr. Knightley, I wish you had the benefit of this; I think this would convince you. For once in your life you would be obliged to own yourself mistaken. An excellent charade indeed! and very much to the purpose. Things must come to a crisis soon now" (Austen 1998: 69). Despite her baseless evaluations, Mr. Knightley rightly thinks that Emma misunderstands Mr. Elton's intentions. His description of Mr. Elton reveals the degree to which he knows people, as well as showing how much he cares for Emma. This is the second time in the novel that he benevolently tries to help Emma so that she can understand her mistake:

"Depend upon it, Elton will not do. Elton is a very good sort of man, and a very respectable vicar of Highbury, but not at all likely to make an imprudent match. He knows the value of a good income as well as anybody. Elton may talk sentimentally, but he will act rationally. He is as well acquainted with his own claims, as you can be with Harriet's. He knows that he is a very handsome young man, and a great favourite wherever he goes..." (Austen 1998: 63)

Mr. Knightley's evaluation of Mr. Elton and Harriet as an "imprudent match" implies the imprudent nature of Emma's behaviour generally. As he suggests, she is unable to think about the consequences of her own fancies, as she fails to differentiate between sentimentality and rationality. Mr. Knightley warns Emma about her mistakes whenever he has the chance, telling her, for example, that she is unknowingly encouraging Mr. Elton's feelings for her through her own actions. He tries to make her understand that Mr. Elton is not interested in Harriet, but in Emma herself, and that she has caused that. Their dialogue on this subject reveals their two diverging patterns of thought: 
"... he seems to have a great deal of good-will towards you." "Me!" she replied with a smile of astonishment, "are you imagining me to be Mr. Elton's object?"

"Such an imagination has crossed me, I own, Emma; and if it never occurred to you before, you may as well take it into consideration now."

"Mr. Elton in love with me!-What an idea!"

"I do not say it is so; but you will do well to consider whether it is so or not, and to regulate your behaviour accordingly. I think your manners to him encouraging. I speak as a friend, Emma. You had better look about you, and ascertain what you do, and what you mean to do."

"I thank you; but I assure you you are quite mistaken. Mr. Elton and I are very good friends, and nothing more..." (Austen 1998: 105-106)

Emma's reaction to Mr. Knightley's warnings reveals two aspects of her character. First, it displays her inability to read people's thoughts and intentions from their behaviour. Second, it shows the degree to which she is resistant to any viewpoints besides her own. Her evaluation of Mr. Knightley's words after his departure reveals her tremendous self-confidence. She denounces him as a person whose "blunder $[\ldots]$ often arise[s] from a partial knowledge of circumstances" (Austen 1998: 106). In re-evaluating her argument with Mr. Knightley and using his own discourse against him, Emma not only rejects his thoughts, but also accuses him of not having sound judgement, as he is making the "mistakes which people of high pretensions to judgment are for ever falling into" (Austen 1998: 106). As a result, she increasingly feels dissatisfied with the way Mr. Knightley thinks about her ability to judge, although she finally discovers that he is correct.

On hearing Mr. Elton's confession of his love for her, Emma admits her mistake, saying "I have been in a most complete error with respect to your views, till this moment" (Austen 1998: 123). For the first time in the novel, Emma faithfully reflects on her actions. Although this event affects her deeply, it does not bring about a fundamental change in her evaluation system:

Emma sat down to think and be miserable.- It was a wretched business indeed! - Such an overthrow of every thing she had been wishing for!Such a development of every thing most unwelcome!- - Such a blow for Harriet! - that was the worst of all. Every part of it brought pain and humiliation, of some sort or other; but, compared with the evil to Harriet, all was light; and she would gladly have submitted to feel yet more mistaken - more in error - more disgraced by mis-judgment, than she actually was, could the effects of her blunders have been confined to herself. (Austen 1998: 125)

Emma's emotions here, aroused by the unwanted consequences of her lived experiences, do not bring about a substantial change in her evaluations. Despite her awareness of the major part she has played in what happened between Mr. Elton and Harriet, Emma seems not to learn any lessons about her own judgment 
from this event. Her failure to match Harriet with Frank Churchill and her own temporary affair with him, however, enhance Emma's tendency to re-evaluate her actions and thoughts before the remarkable transformation in her perspective.

\subsection{Emma and Frank Churchill}

Emma's experience with Frank Churchill raises her awareness of her mistakes. Frank Churchill's presence reveals the dominant aspects of Emma's character even more. When Mr. Knightley criticises Frank for suddenly going to London "merely to have his hair cut short [...] just the trifling, silly fellow I took him for" (Austen 1998: 191), it arouses Emma's emotional defence of her new object of desire. Having heard about Frank Churchill's return from London, she reflects on his actions, while at the same time evaluating Mr. Knightley's derogatory comment about him:

"I do not know whether it ought to be so, but certainly silly things do cease to be silly if they are done by sensible people in an impudent way. Wickedness is always wickedness, but folly is not always folly.- It depends upon the character of those who handle it. Mr. Knightley, he is not a trifling, silly young man. [...] - No, I am perfectly sure that he is not trifling or silly." (Austen 1998: 196)

This defence of Frank Churchill, coloured by her fancies, gradually leads Emma towards the thought that he is "more in love with her than Emma had supposed" (Austen 1998: 241) Nevertheless, just as she was unable to identify Mr. Elton's love for herself, she is unable to identify Frank's love for Jane Fairfax. This misidentification derives from her tendency to ascribe wrong or non-existent intentions both to herself and to others. When she reviews her attachment to Frank, she sees "no doubt of her being in love" despite the fact that she finds "the conclusion of every imaginary declaration on his side was that she refused him" (Austen 1998: 243). Through identifying her ambivalence towards Frank, Emma begins to recognise her own uncertainty, and even ignorance, about what she really feels.

The determinate nature of Emma's thoughts and actions, however, changes during the third part of the novel. She admits to herself that "her own attachment [to Frank] had really subsided into a mere nothing; it was not worth thinking of" (Austen 1998: 291). Having suppressed her own interest in Frank, Emma observes him closely, as she hopes to match him with Harriet. Her intention to do so is, again, not only for the sake of her friend. Instead, she pursues aretaliation against her own previous failure. Ignoring Mr. Knightley's negative evaluation of Frank Churchill's character and intentions, she provokes Harriet's interest in Frank. The announcement of Frank Churchill's and Jane Fairfax's secret engagement drives Emma to acknowledge her own mistakes and inspires pity for Harriet: “'Harriet, poor Harriet!'-Those were the words; in them lay the tormenting ideas which Emma could not get rid of, and which constituted the real misery of 
the business to her" (Austen 1998: 371). It also arouses her own critical re-evaluation of the process that she has manipulated. She admits that, more than anyone else, she is responsible for the situation: "Frank Churchill had behaved very ill $[\ldots]$ but it was not so much his behaviour as her own, which made her so angry with him. It was the scrape which he had drawn her into on Harriet's account, that gave the deepest hue to his offence" (Austen 1998: 371-372). For the first time in the novel, she acknowledges the validity of Mr. Knightley's precautions, "Mr. Knightley had spoken prophetically, when he once said, 'Emma, you have been no friend to Harriet Smith" (Austen 1998: 372). Comparing this situation to the Mr. Elton incident, Emma here blames herself more seriously for causing Harriet's pain. This time, a change in her attitude towards her own (mis)deeds shows itself. However, she still thinks that she cannot be considered the "sole and original author" of her friend's "mischief," and she regrets that she did not use her own "influence" to stop her friend from the misery:

She was afraid she had done her nothing but disservice.- It was true that she had not to charge herself, in this instance as in the former, with being the sole and original author of the mischief; with having suggested such feelings as might otherwise never have entered Harriet's imagination; for Harriet had acknowledged her admiration and preference of Frank Churchill before she had ever given her a hint on the subject; but she felt completely guilty of having encouraged what she might have repressed. She might have prevented the indulgence and increase of such sentiments. Her influence would have been enough. And now she was very conscious that she ought to have prevented them. (Austen 1998: 372)

This experience has a profound psychological impact on Emma. Together with the other experiences she goes through in the novel, it enhances her awareness of perspectives outside her own. Her later confession to Mr. Knightley is one of the effects of this incident. She gradually understands that her "common sense" is insufficient to identify what is right and what is wrong for herself and for others. This experience is an important step of her cognitive development. For the first time in the novel, she accepts that she needs more (than) everyday sense to understand these issues, "she felt that she had been risking her friend's happiness on most insufficient grounds. Common sense would have directed her to tell Harriet, that she must not allow herself to think of him, and that there were five hundred chances to one against his ever caring for her-- 'But, with common sense,' she added, 'I am afraid I have had little to do"' (Austen 1998: 372).

Emma gains some self-knowledge through her experiences with Frank Churchill and recognises that she shares some of his character traits. When they see each other in the novel's final scene, they share "a number of embarrassing recollections" about their experiences (Austen 1998: 440). Emma is also aware that both of their marriages have something in common, since Mr. Knightley and Jane Fairfax are their superiors. Such a mutual understanding and confession brings 
about narrative justice in the end:

'If not in our dispositions,' she presently added, with a look of true sensibility, 'there is a likeness in our destiny; the destiny which bids fair to connect us with two characters so much superior to our own.'

'True, true,' he answered, warmly. 'No, not true on your side. You can have no superior, but most true on mine.--She is a complete angel.' (Austen 1998: 442)

Accordingly, it is through Frank Churchill that Emma indirectly confesses her own misperceptions and flawed evaluations about Jane Fairfax. Since this is the last scene of the novel, it shows that Emma's change is not temporal or limited to her interactions with one person or event. Instead, it is a profound behavioural transformation. Her experiences with Jane Fairfax and Miss Bates prior to this transformation also contribute to her emotional and cognitive development.

\subsection{Emma, Jane Fairfax and Miss Bates}

Emma's judgements and perceptions about Jane Fairfax and her aunt Miss Bates are initially negative. These lead to some bitter, but constructive, disagreements with Mr. Knightley and Emma's eventual realisation of her mistakes, which contributes to the change in her attitudes towards the other characters. Before Jane arrives in Highbury, Miss Bates incessantly talks about the letters Jane sends to them from London, and Emma's jealousy of her is apparent from the very beginning. The moment she is told that Jane is going to come back to Highbury, Emma begins her long and detailed process of speculation about what Jane's motives could be for returning:

"One might guess twenty things without guessing exactly the right; but I am sure there must be a particular cause for her chusing to come to Highbury instead of going with the Campbells to Ireland. Here, she must be leading a life of privation and penance; there it would have been all enjoyment. As to the pretence of trying her native air, I look upon that as a mere excuse." (Austen 1998: 201)

She concludes that the reason Jane is leaving the Campbells in London is that she is in love with their would-be son-in-law, Mr. Dixon. Through fictionalising what she knows nothing about (or only knows partially), Emma invents reasons for disliking Jane. However, the true nature of her dislike can be seen in Mr. Knightley's evaluation:

Why she did not like Jane Fairfax might be a difficult question to answer; Mr. Knightley had once told her it was because she saw in her the really accomplished young woman, which she wanted to be thought herself; and 
though the accusation had been eagerly refuted at the time, there were moments of self-examination in which her conscience could not quite acquit her. (Austen 1998: 154)

Emma's presuppositions and pride, therefore, act as insurmountable obstacles to her correct evaluation of Jane Fairfax's character. Even more than her mistake about Mr. Elton, this experience reveals some dark aspects of Emma's character. The fact that she is unable to rationalise her own interpretation of Jane Fairfax's situation, even to herself, shows the unconvincing nature of her own system of reason. She finds herself unable to fully interpret her feelings about Jane:

But 'she could never get acquainted with her: she did not know how it was, but there was such coldness and reserve - such apparent indifference whether she pleased or not — and then, her aunt was such an eternal talker! — and she was made such a fuss with by everybody! - and it had been always imagined that they were to be so intimate - because their ages were the same, everybody had supposed they must be so fond of each other.' These were her reasons - she had no better. (Austen 1998: 154)

Emma's "self-examination" about her feelings towards Jane Fairfax, as well as her evaluation of her motives, however, leads her towards a recognition of Jane Fairfax's true nature. As a result of her critical reflections, triggered by Mr. Knightley's comments on the situation, she is able to base her evaluations of Jane's character on contextual realities rather than her own jealousy. When Harriet compares Emma's skill on the piano to that of Jane Fairfax, Emma explicitly denies the comparison:

'Oh! if I could but play as well as you and Miss Fairfax!'

'Don't class us together, Harriet. My playing is no more like hers than a lamp is like sunshine.' (Austen 1998: 214)

This dismissal of Harriet's flattery is not an emotional reaction to the situation, but a rational one based on evidence. The fact that she can finally approve of Jane Fairfax by the novel's end reveals how Emma gradually experiences a cognitive development in her character. For example, when Frank mentions her theory about Jane and Mr. Dixon at the end of the novel, Emma exclaims, "I can never think of it [...] without extreme shame" (Austen 1998: 441). Here she questions the validity of her own evaluation system, and blames herself for her misconceptions. Such a discovery enables her to evaluate the situation not solely from the perspective of her own self-interest, but from other perspectives as well. The same kind of change is also boosted by her experiences with Miss Bates.

Miss Bates is a spinster in her forties. She is well loved in Highbury society, as she connects its residents to each other through participating in the gossip culture of the neighbourhood. During a party, Emma, anxious about what the others 
might think about her talking with Frank Churchill, suddenly desires to know what they "may all be thinking of" (Austen 1998: 342). Frank says that Emma demands of each of them "either one thing very clever, be it prose or verse, original or repeated, or two things moderately clever, or three things very dull indeed, and she engages to laugh heartily at them all" (Austen 1998: 342). Miss Bates' reaction to this demand is as follows:

'Oh! very well,' exclaimed Miss Bates, 'then I need not be uneasy. 'Three things very dull indeed.' That will just do for me, you know. I shall be sure to say three dull things as soon as ever I open my mouth, shan't I? - (looking round with the most good-humoured dependence on everybody's assent)Do not you all think I shall?' (Austen 1998: 343)

Emma's reaction to Miss Bates' sincere discourse is deeply pejorative: “"Ah! Ma'am, but there may be a difficulty. Pardon me - but you will be limited as to number-only three at once"' (Austen 1998: 343). The omniscient narrator's subsequent comment shows both the deep impact of Emma's words on Miss Bates and the awareness of their destructive impact by everyone around her, "when it burst on her, it could not anger, though a slight blush showed that it could pain her" (Austen 1998: 343). Despite the fact that Miss Bates is visibly hurt, Emma only recognises the pain she has caused through her re-evaluations of the situation when speaking with Mr. Knightley. When Mr. Knightley condemns her for her disrespectful comment to Miss Bates, she is deeply affected, not because of Miss Bates's feelings, but because of the impact of her misbehaviour on Mr. Knightley himself. She shows some signs of emotional attachment to Mr. Knightley for the first time when she realises how he has tried to improve and modify her thoughts:

She was vexed beyond what could have been expressed - almost beyond what she could conceal. Never had she felt so agitated, mortified, grieved, at any circumstance in her life. She was most forcibly struck. The truth of this representation there was no denying. She felt it at her heart. How could she have been so brutal, so cruel to Miss Bates! How could she have exposed herself to such ill opinion in any one she valued! And how suffer him to leave her without saying one word of gratitude, of concurrence, of common kindness! (Austen 1998: 348)

Emma's recollection of the scene influences her thoughts seriously. She finds herself in love with Mr. Knightley: "time did not compose her. As she reflected more, she seemed but to feel it more. She never had been so depressed" (Austen 1998: 348). Consequently, she tries to correct her mistakes. Although she primarily does so in order to improve her standing with Mr. Knightley, when she goes to Miss Bates' house to apologise, she experiences a perspectival change that goes beyond Mr. Knightley's good opinion of her: 
Emma was most sincerely interested. Her heart had been long growing kinder towards Jane; and this picture of her present sufferings acted as a cure of every former ungenerous suspicion, and left her nothing but pity; [ . . ] She spoke as she felt, with earnest regret and solicitude - sincerely wishing that the circumstances which she collected from Miss Bates to be now actually determined on, might be as much for Miss Fairfax's advantage and comfort as possible. (Austen 1998: 351)

Her positive evaluation of Miss Bates and Jane Fairfax improves her judgment, and it is only after this growth that the novel allows Emma and Mr. Knightley to express their love for each other publicly.

\subsection{Emma and Mr. Knightley}

Mr. Knightley is the only character who accompanies Emma throughout all the narrative's events and situations and really cares about her behaviour. That is why their marriage at the end of the novel does not surprise the reader since, as Wiltshire states, "it is almost as if Austen were presenting Emma and Mr. Knightley as an already married couple" (75). Emma, nevertheless, denies her interest in Mr. Knightley or, as Wiltshire points out, her "desire for Mr. Knightley (as distinct from her admiration and regard for him) is out of her own awareness - impeded by her devotion to her father" (73). Their marriage implies both their similarities and the fact that he will protect her from the dangers of her own imagination.

Mr. Knightley is represented as the only character who has the emotional and cognitive capacity to identify Emma's mistakes and talk to her about them. $\mathrm{He}$ criticises her publically for her thoughts and deeds in different situations. His comments, however, are mostly disturbing to her, since she is not accustomed to be questioned, "Mr. Knightley loves to find fault with me" (Austen 1998: 12). He intends to help her refine her character, and his evaluations of her behaviour throughout the novel reveal the difference between the real Emma and the Emma he thinks she should be. Despite his efforts, it is only after experiencing the critical events with Harriet, Robert Martin, Mr. Elton, Miss Bates, Jane Fairfax and Frank Churchill that Emma finally is able to admit Mr. Knightley's rational superiority in the last scene of the novel: "What had she to wish for? Nothing, but to grow more worthy of him, whose intentions and judgment had been ever so superior to her own. Nothing, but that the lessons of her past folly might teach her humility and circumspection in future" (Austen 1998: 439). This new Emma is the result of both Mr. Knightley's persistent attention and their mutual love. Thus, she endorses the imprudent nature of her own past actions and in doing so consciously combines her own evaluations with Mr. Knightley's rational side. Her confessional discourse towards the novel's end mainly derives from her experiences of failed matchmaking.

The fundamental change in Emma's character, therefore, could hardly happen without Mr. Knightley's presence. At the beginning of the novel, mesmerised by 
the role she thinks she played in Miss Taylor's and Mr. Weston's marriage, Emma boasts of her "success" to her father and Mr. Knightley, saying,

'And you have forgotten one matter of joy to me,' said Emma, 'and a very considerable one- that I made the match myself. I made the match, you know, four years ago; and to have it take place, and be proved in the right, when so many people said Mr. Weston would never marry again, may comfort me for anything.' (Austen 1998: 13)

Emma's interpretation of the marriage provokes Mr. Knightley's profound disagreement. The scene also carries a teleological significance for both Emma and for the novel's plot. Nearly all the succeeding narrative events show that Mr. Knightley was right by asking Emma to take precautions in her actions for her own sake. It also reveals how Emma finally agrees with Mr. Knightley:

"I do not understand what you mean by 'success,"” said Mr. Knightley. "Success supposes endeavour. Your time has been properly and delicately spent, if you have been endeavouring for the last four years to bring about this marriage [...] But if, which I rather imagine, your making the match, as you call it, means only your planning it, your saying to yourself one idle day, 'I think it would be a very good thing for Miss Taylor if Mr. Weston were to marry her,' and saying it again to yourself every now and then afterwards, why do you talk of success? Where is your merit? What are you proud of? You made a lucky guess; and that is all that can be said." (Austen 1998: 14)

This is the first narrative situation when Mr. Knightley openly criticises Emma for overemphasising her fancies. Implying the supremacy of performing any practical action over simply thinking about it, he blames her for relying on her imagination alone. In this way, as Ermarth points out, Mr. Knightley "directly provides corrective pressure" (149) on Emma throughout the narrative.

When Emma slightly criticises Mr. Knightley, telling him “"our opinions are sometimes very different," his response reveals what he considers to be the main sources of her deficiencies: "If you were as much guided by nature in your estimate of men and women, and as little under the power of fancy and whim in your dealings with them. [...] I have still the advantage of you by sixteen years' experience, and by not being a pretty young woman and a spoiled child"' (Austen 1998: 93). As a result of their close interaction and exchange of ideas, Mr. Knightley makes Emma's change possible. Acting against her previous criticism, she gradually shows affection towards him. For example, when Mrs. Weston talks about the possibility of Mr. Knightley's marriage to Jane Fairfax, Emma exclaims: "Mr. Knightley must not marry" (Austen 1998: 207). She calls it a "mad thing" (Austen 1998: 208) which is "evil to himself" (Austen 1998: 20). The idea of his marriage awakens Emma's unconscious romantic feelings towards him. 
When Mr. Knightley reminds Emma that the Eltons' insulting behaviour at the ball was due to the fact that she "did want him to marry Harriet," their conversation changes into an exchange of thoughts leading them to mutual confession. Mr. Knightley's maturity helps him to extract Emma's first open repentance. Instead of telling her what to do, he emboldens her to (re)configure her own evaluations and thoughts based on reality:

"I shall not scold you. I leave you to your own reflections."

"Can you trust me with such flatterers?-Does my vain spirit ever tell me I am wrong?"

"Not your vain spirit, but your serious spirit.- If one leads you wrong, I am sure the other tells you of it." (Austen 1998: 305)

Emma's experiences with Mr. Knightley gradually help her to identify and admit her misconception about Mr. Elton: "I do own myself to have been completely mistaken in Mr. Elton. There is a littleness about him which you discovered, and which I did not: and I was fully convinced of his being in love with Harriet. It was through a series of strange blunders!'” (Austen 1998: 305-306). As a result of her sincere discourse, Mr. Knightley is also encouraged to admit his previous flawed evaluation of Harriet:

"And, in return for your acknowledging so much, I will do you the justice to say, that you would have chosen for him better than he has chosen for himself.-Harriet Smith has some first-rate qualities, which Mrs. Elton is totally without. An unpretending, single-minded, artless girl-infinitely to be preferred by any man of sense and taste to such a woman as Mrs. Elton. I found Harriet more conversable than I expected." (Austen 1998: 306)

Such a mutually-reassuring discourse is satisfactory to both sides, and it makes their marriage possible. It is only after experiencing such reflective moments that Emma can express her love for Mr. Knightley. She is surprised by her fresh emotion: "'How long had Mr. Knightley been so dear to her, as every feeling declared him now to be? When had his influence, such influence begun? - When had he succeeded to that place in her affection, which Frank Churchill had once, for a short period, occupied?"' (Austen 1998: 381). Emma evaluates the nature of her new self by comparing her love for Mr. Knightley to the romantic feeling she once felt for Frank Churchill:

She saw that there never had been a time when she did not consider Mr. Knightley as infinitely the superior, or when his regard for her had not been infinitely the most dear. She saw, that in persuading herself, in fancying, in acting to the contrary, she had been entirely under a delusion, totally ignorant of her own heart - and, in short, that she had never really cared for Frank Churchill at all! (Austen 1998: 381) 
The more she acknowledges Mr. Knightley's supremacy, the more she criticises the flawed nature of her previous actions: "with insufferable vanity had she believed herself in the secret of every body's feelings; with unpardonable arrogance proposed to arrange every body's destiny. She was proved to have been universally mistaken; and she had not quite done nothing - for she had done mischief" (Austen 1998: 382). Her constant reflections reveal her transformative process of finally being able to know herself.

Likewise, Mr. Knightley's proposal is the result of a remarkable change in Emma's character. Because of his close observations, he is aware of the way her character has been evolving under the influence of her experiences. He is able to discern that she has finally achieved his desired balance between her imagination and reason. She is also aware of the change in his perspective, and no longer finds his corrective discourse offensive. When they are talking about Harriet's and Mr. Martin's marriage, they both are subjected to some kind of change which results in their close communion,

"I am perfectly satisfied," replied Emma, with the brightest smiles, "and most sincerely wish them happy."

"You are materially changed since we talked on this subject before." "I hope so-for at that time I was a fool."

"And I am changed also; for I am now very willing to grant you all Harriet's good qualities. I have taken some pains for your sake, and for Robert Martin's sake, (whom I have always had reason to believe as much in love with her as ever,) to get acquainted with her. I have often talked to her a good deal." (Austen 1998: 438)

Emma's education through her experiences with Miss Taylor, Harriet Smith, Robert Martin, John Elton, Frank Churchill, Miss Bates and Jane Fairfax gradually bring about an operational flexibility in her thoughts. Additionally, Mr. Knightley's constant care and encouragement help her to refine her perspective. She learns to ground her evaluations not solely on her fancies but on the realities of the storyworld as well. Mr. Knightley accompanies her in all her major experiences, warns her against her mistakes, and enables her to discover her own feelings. Through her continuous interaction with him, she learns about the unreliable nature of her own fancies and the reliable power of Mr. Knightley's thoughts and inferences.

\section{Conclusion}

Emma foregrounds the centrality of experience to the main character's cognitive, emotional and behavioural development. It can be read as a clinical narrative of experience, a Bildungsroman which displays the significance, or inevitability, of 
personal experiences in one's growth and development. Emma's egocentric character at the beginning evolves into a sympathetic one at the end. The narrative uses situations, such as Emma's attempt to shape Harriet's destiny, to portray how Emma's evaluations of the other characters are primarily controlled by her imagination. Orienting all her experiences towards a transformational and confessional moment for both Mr. Knightley and Emma herself, the implied author supports Mr. Knightley's critical and corrective perspective of Emma's thoughts and actions. In other words, through her experiences Emma not only learns to sympathise with the other characters, but also becomes aware of the flawed nature of her own evaluations. As a result of such emotional and cognitive changes, she is finally able to embrace the other characters in Highbury. The impact of her experiences on her development is, therefore, undeniable. This quality of narrative has the potential to produce cognitive, emotional and even behavioural responses to the narrative situations in the reader. When Emma successively makes false inferences about the other characters, as Mr. Knightley and the implied author do, the reader also experiences the same kind of psychological tension. In other words, besides being represented semiotically in the narrative itself, experientiality in Emma depends on the reader's familiarity with the represented narrative experience. The final transformation, accordingly, is a transformation both within the narrative horizon and the experiential horizon of the reader. These characteristics add to the narrativity level of Austen's novel. They present Emma's subjective (re)evaluations of the narrative events and situations, and their impact both on the operation of her consciousness and on the experiencing mind of the reader. This extra narrative layer can perhaps account for the universal popularity of Austen's novel over the years.

\section{References}

Austen, Jane (1998) Emma. New York: Könemann.

Booth, Wayne C. (1961) The Rhetoric of Fiction. Chicago: The University of Chicago Press.

Caracciolo, Marco (2012) 'Notes for a(nother) Theory of Experientiality'. Journal of Literary Theory 6(1), 177-194.

Dabney, Townsend (2010) The A to Z of Aesthetics: The A to Z Guide Series, No. 154. Lanham: The Scarecrow Press, Inc.

Ermarth, Elizabeth Deeds (1998) Realism and Consensus in the English Novel: Time, Space and Narrative. Edinburgh: Edinburgh University Press.

Fludernik, Monica (2005) Towards a Natural Narratology. London: Routledge.

Herman, David (2009) Basic Elements of Narrative. Oxford: Wiley-Blackwell.

Hecimovich, Gregg A. (2008) Austen's Emma. London: Continuum.

Klemann, Heather M. (2012) 'Ethos in Jane Austen's Emma'. Studies in Romanticism 51(4), 503532.

Leavis, F. R. (1950) The Great Tradition. New York: George W. Stewart, Publisher Inc.

Lodge, David (2002) Consciousness and the Novel: Connected Essays. Massachusetts: Harvard University Press. 
Popova, Yanna B. (2015) Stories, Meaning and Experience: Narrativity and Enaction. New York: Routledge.

Showalter, Elaine (1977) A Literature of Their Own: British Women Novelists from Bronte to Lessing. Princeton: Princeton University Press.

Southam, B.C. (ED.) (2005) Jane Austen, Volume I, 1811-1870: The Critical Heritage. London: Routledge.

Todd, Janet (2006) The Cambridge Introduction to Jane Austen. Cambridge: Cambridge University Press.

Wiltshire, John (1997) 'Mansfield Park, Emma, Persuasion'. In: Copeland, Edward and Juliet McMaster (eds.) The Cambridge Companion to Jane Austen. Cambridge: Cambridge University Press, 58-83.

Karam NayebPour, Ph.D., teaches English Literature at the Faculty of Letters, Karadeniz Technical University, Turkey. His research areas include Narratology, Literary Theory and Criticism, and Anglo-American fiction, He has published various articles on English Literature in scientific journals. His book, Mind Presentation in Ian McEwan's Fiction: Consciousness and the Presentation of Character in Amsterdam, Atonement, and On Chesil Beach (2017), has recently been published by ibidem Press (via Colombia University Press).

Address: Asst. Prof. Dr. Karam Nayebpour, Faculty of Letters, Department of English Language and Literature, Karadeniz Teknik Üniversitesi (KTÜ), 61080 Trabzon, Turkey. [email: knayebpour@ktu.edu.tr; knayebpour@gmail.com] 
